\title{
RURAL LANDSCAPE DEVELOPMENT POLICY IN POLAND - SOME ASPECTS OF SUSTAINABILITY
}

\section{POLITIKA ROZVOJA VIDIECKEJ KRAJINY V POL'SKU - - NIEKTORÉ ASPEKTY UDRŽATEL'NOSTI}

\author{
Józef MOSIEJ*
}

\section{Introduction}

The very definition of 'rurality' is of course that it is a sparsely inhabited area, from which follows that it is further away from the large urban areas. In short, the EU definition is based on a definition initially introduced by the OECD that a rural area is an area with a population density of less than 150 inhabitants per $\mathrm{km}^{2}$. A rural region is predominantly rural if more than $50 \%$ of the population of the region is living in rural communities with less than 150 inhabitants $/ \mathrm{km}^{2}$. According to this standard definition, more than $91 \%$ of the territory of the EU is 'rural' or 'predominantly rural', and this area is home to more than $56 \%$ of the EU population. Human activities, mainly in agriculture and forestry, influence the rural landscape to a large extent.

The types of farming and forest production practiced in Europe today are largely governed by the EU legislation and the EU economic incentives, especially in the EU Member States. In addition, the development of other rural activities is stimulated by the EU regional and rural development policies.

Natural ecosystems change, but perhaps not as drastically as human environments. However, nature in rural areas is not only affected by climate, geology and other site-specific

\section{Abstract (EN)}

In the recent years, when it comes to topics concerning rural areas and agriculture, sustainability has become a key term resonating in the political, economical, social and environmental discussions. These issues are discussed across the globe and Poland is not an exception. There are many features that have impact on sustainability. Among others it is situation in agricultural production, employment in agriculture, access to the land and situation at the land market, aspects of the environmental protection or the administrative structure of the country. Therefore, the main objective of the presented paper is to a comprehensive summary of different aspects influencing rural development in Poland with an emphasis on sustainability. Based on the conducted analysis it can be stated that even though many positive changes have been implemented in the Polish reality, there are still many issues with need to be urgently addressed.

\section{Keywords (EN)}

rural development, agriculture, sustainability, rural development policy properties, but it is also much affected and sometimes more or less destroyed by human activities, especially wars, pollution, urban expansion, mining, energy installations, infrastructure, agricultural practices, etc.

A process aimed at local or regional definition of sustainable rural development should always involve local stakeholders. Thus, the freedom of local people to define their own needs and take part in decisions that affect their own lives is a cornerstone in defining how to achieve sustainable rural development.

Having said that, we can only give general comments on the key challenges for sustainable rural development ${ }^{(1)}$ :

- the organization of human activities in the landscape to protect and manage global and long-term resources,

- keeping and maintaining ecosystems,

- supporting long-term biodiversity,

- establishing the necessary interactions between urban and rural areas,

- developing a sound economy, including job opportunities, etc.,

1) Karlsson, Rydén,Sepp (2013)

\section{Abstrakt (SK)}

Pokial ide o témy týkajúce sa vidieckych oblastí a polnohospodárstva, udržatel'nost' sa stala klúčovým pojmom rezonujúcim v posledných rokoch v politických, ekonomických, sociálnych a environmentálnych diskusiách. Otázka udržatel'nosti je prítomná v krajinách po celom svete a Pol'sko nie je výnimkou. Existuje mnoho aspektov, ktoré majú vplyv na udržatel'nost'. Okrem iného je to situácia v pol'nohospodárskej výrobe, zamestnanost’ v polnohospodárstve, prístup k pôde a situácia na trhu s pôdou, aspekty ochrany životného prostredia alebo administratívna štruktúra krajiny. Hlavným cielom prezentovaného príspevku je preto komplexné zhrnutie rôznych aspektov ovplyvňujúcich rozvoj vidieka v Polsku s dôrazom na udržatel'nost'. Na základe vykonanej analýzy je možné konštatovat', že aj ked' sa v Pol'sku realizovalo mnoho pozitívnych zmien, stále existuje vela otázok, ktoré treba urýchlene riešit'.

\section{Klúčové slová (SK)}

rozvoj vidieka, pol'nohospodárstvo, udržatel'nost', politika rozvoja vidieka 
- developing good social conditions regarding inequities, gender issues, indigenous peoples, other minority groups, etc.

\section{Economic and ecologic context of the changes in Poland}

In the last 30 years, the issue of sustainability, beyond the short period at the beginning of the economic and political changes since 1991 and partly in the course of negotiations before the Polish accession to the EU, has never received a high position on the political agenda. The primary investment policy is the creation of new production capacity or new service capabilities, rather than seeking to meet social needs in the most costeffective, socially and environmentally suitable way, with the use of existing assets, its modernization and change of the function or the application of modern systems management ${ }^{(2)}$.

The year 2019 in the case of Poland is the 30th year of the continuous economic growth, reflected in the doubled value of GDP (as compared with that of 1989) and reduced difference between Poland and well-developed EU member states. These are the most synthetic measures of the development success in Poland. What is the share of rural areas and agriculture in this success and the benefits thus achieved? ${ }^{(3)}$

At the same time there was a significant opportunity to improve resource efficiency, so as not to waste resources in a manner characteristic for the Polish economy until 1989. The introduction of the market economy and the recession in its early stages, then the introduction of modern and therefore more fuel-efficient technologies have contributed to the economic development of the Polish economy and virtually to no increase in the consumption of resources. Between the years 2000 and 2012, resource productivity improved by $25 \%{ }^{(4)}$. But still, despite the improvement in the efficiency of utilization of natural resources, the productivity in Poland is 2-3 times lower than in the richer countries. Along with the increase in the efficiency of the use of resources, the process of building an environmental infrastructure is underway. It is worth emphasizing that the purpose of the significant resources allocation - the protection of the environment is guided by $7-9 \%$ of all expenditures for investments in Poland, which is 2-2.5 billion Euro per year. Only 20\% of this amount comes from the EU funds. Examples of these investments from the years 1995-2012 are: a wastewater treatment plant, which was opened with a total capacity of 4.3 million $\mathrm{m} 3$ per day, equipment to capture dust pollution of air with a capacity of 2.2 million tonnes per year and an equipment for capturing of gaseous pollutants with a capacity of 2 million tonnes per year. As a result of these investments, there has been a significant reduction of emissions and improvement of quality of the environment, particularly water quality in rivers and lakes, and air.

On the other hand, the period of transition, characterized by rapid economic development and the creation of a consumer society foundations, brought new threats to the environment.

\footnotetext{
(2) Karaczun, Kassemberg, Owczarek (2015)

(3) Wilkin (2014)

(4) Eurostat
}

These are primarily:

- mass motorization with increasing emissions and fragmentation of the landscape through the construction of new roads,

- an increase in the mass consumer waste, including packaging,

- progressive intensification of agriculture, together with the increase of the famr size, which threatens biodiversity,

- rapid spread of cities - between the years 1990 and 2012 the share of agricultural land and non-forest lands of the total area of the country has increased from $12.7 \%$ to $22 \%$,

- loss of biodiversity - progressing from the western part of Poland eastward. The largest share in the transport, agriculture and small and medium-sized enterprises, localized on natural sensitive areas,

- excessive uncontrolled tourism (also in relation to the areas protected by law).

Moreover, despite significant progress, the quality of water still leaves much to be desired. Furthermore, while the years 1990 2012 had shown a decrease of emissions of key pollutants, from 2004 the rate of decrease has slowed down significantly.

\section{Agricultural landscape in Poland - current state}

Sustainable development of agriculture, food and forestry, in relation to Poland, requires adaptation to the national specificities resulting from the structure of Polish agriculture and the natural conditions. This applies to all specific objectives: access to food, increased productivity, equal access to agricultural land and sustainable agriculture.

Polish agriculture, both in terms of the area of arable land, as well as in terms of the level of development and modernization that has occurred in recent years, especially after the accession to the European Union, is able not only to ensure food self-sufficiency of the country, but also produces a surplus products allocated for export. In recent years, Poland has become a major exporter of fruits, eggs and meat products. The increase in production is, however, largely at the expense of increasing pressure exerted on the natural environment.

Until the mid-twenties, Poland was an agricultural country. In the 1950s, over half of the working population was engaged in agriculture, and agriculture formed almost $40 \%$ of the GDP. In 1989 (the beginning of political and economic transformation), agriculture still accounted for $26.4 \%$ of jobs and $12.8 \%$ of the GDP: three times more than in developed countries. Polish agriculture has a diverse character. On the one hand, there are small farms with surface area from 1-10 hectares, which form $75 \%$ of the total number of farms (in absolute number $1405700)^{(5)}$. According to the Main Statistical Office (2017) they use only $28 \%$ of the agricultural land. On the other hand, there are also farms operating on

larger areas (over 10 hectares), whose total share in the total number of farms is around 25\% (including the largest farms, above 50 ha $-2.5 \%$ ) and they use about $72 \%$ of the agricultural land ${ }^{(6)}$.

\footnotetext{
(5) Sobiesiak-Penszko, Pazderski, Jakubowska-Lorenz (2019)

(6) Agrifood Atlas (2017)
} 
Polish rural landscape is diverse both internally and regionally ${ }^{(7)}$. While in the west and north - western Poland it is dominated by large farms and intensive agricultural production, in central and southern Poland small farms prevail producing mainly for their own needs. Nationally, only about 20\% of households produce for the market. Most of them produce only or mostly for their own needs. This results in a varying degree of sustainability of production. In some parts of the country (central, south, and southeast of the country), agricultural production is sustainable from the environmental point of view, not exerting undue influence on it, but at the expense of economic efficiency - low production (mostly for own consumption) and lower farm incomes. Other regions (northwest of the country) are dominated by large intensive farms, or even industrial production, with a strong, negative impact on the natural environment, but creating positive economic results and generating significant surplus of crops. Strengthening the positive trend necessitates a differentiated policy for individual regions and differentiated agricultural policy instruments, aimed at achieving different goals. This is partly implemented through diversification of activities that will be supported under the provincial (regional) operational programs supported by the EU and partly through diverse possibilities of application of agricultural policy instruments in relation to the location of the holdings (agricultural subsidies aimed at lessfavoured areas, support for regional differences agri - climate - environment, etc.). Finally, it is also implemented through creating special programs for underdeveloped areas (e.g. Eastern Poland Operational Programme co-financed by the EU in the period 2007-2013).

\section{Equal access to land}

From the point of view of the sustainability of agricultural production, one of the most important factors is to ensure adequate protection of the agricultural land against its permanent transfer to other purposes. Whilst the current technology allows us to perform soilless cultivation, its nature does not have traits of sustainable production.

Agricultural land and forestland in Poland are protected under the Act on the Protection of Agricultural and Forest Plants. On the basis of this law, only land of the lowest fertility category may be used for non-agricultural purposes.

Allocating agricultural land of the highest quality for nonagricultural purposes requires the consent of the Ministry of Agriculture and Rural Development, and the use of forestland for other purposes requires the consent of the Ministry of the Environment (in the case of forestland owned by the state) or marshal of the province (in the case of private forests). For excluding land from agricultural production, fees are charged for both land exclusion and also for its later use.

Food production is a major function of Poland's agricultural sector. It ensures Poland's food self-sufficiency and generates an international trade surplus. Since 2004, the value of food exports from Poland has increased over four-fold. But the growing pressure of urbanization on rural areas threatens this state.

(7) Krasowicz (2012)
Despite the law to protect farmland and forestland, every year significant amount of farming areas are converted to nonagricultural use. Between 2015 and 2016 alone, over 5200 hectares of farmland, including over 3200 hectares of the soil of the highest quality, were lost this way. This is the equivalent of shutting down 570 medium-sized farms, out of which more than 350 cultivate the best soils. This is the result of inefficient spatial planning, which leads to cities sprawling into the rural areas, of road building and the excavation of open cast mines for lignite and minerals. Because a mere 3.7\% of Poland's agricultural land is classified as having "good" or "very good" quality, protecting this precious resource must be a priority. The high quality of Polish food is one of its attractions, but this can be maintained only if the country's agriculture is sustainable. Unfortunately, the pressure to make profit is replacing traditional crop and animal production methods.

Transformation of agricultural land to non-agricultural purposes, the abandonment of afforestation and sustainable use means that between 1989 and 2012 agricultural area decreased by 3677000 hectares (with approx. 18.7 million hectares in 1989 to 14 million hectares). Arable land decreased in a similar extent (about 3.419 million hectares). This means a reduction in the potential production of Polish agriculture by more than $20 \%$ in less than 25 years. Further loss of agricultural land at this rate, especially the land of the highest quality, may mean reduction of life expectancy of agricultural production and the loss of Polish food security. Therefore, from the point of view of sustainable agricultural production, the introduction of stricter requirements to protect agricultural land against its transfer to non-agricultural purposes should be regarded as a priority, particularly by improving the land management policy in Poland. ${ }^{(8)}$

In addition to protecting agricultural land against non-agricultural use, an important factor in the efficiency and sustainability of agricultural production is the existence of a land market, where producers interested in increasing their production can acquire land for cultivation. Unfortunately, the land market in Poland is not very popular. Usually, the owners of small areas give land for lease, and they themselves receive payments from the EU.

The result is that agricultural land prices in Poland are relatively high. Since the end of 2004, when Poland joined the European Union, agricultural land prices in Poland increased by $380 \%$ and currently it is about 6.5 thousand EUR/ha. It is impossible, however, to assess whether this state is due to the real increase in the value and the expected benefit of its cultivation (theoretical value of agricultural products and subsidies per hectare of land in Poland is approx. 1.6 thousand EUR/ year), or other factors - speculative activities and the lack of actual marketing in the land market in Poland

The land market is no longer one of the main barriers to increasing agricultural productivity. It allows the concentration of land on farms producing for the market. Changes in this area are very slow (Table 1), still almost $50 \%$ of agricultural land is owned by farms with an area of less than 15 hectares.

In 2012, $1.8 \%$ of the largest farms had approximately $22.3 \%$ of agricultural land. Fragmentation of production is intensified

(8) Egospodarka (2015) 
Table 1: Farms by size groups in years 1988 - 2017

\begin{tabular}{|c|c|c|c|c|c|c|}
\hline & \multicolumn{6}{|c|}{ Year } \\
\hline & 1988 & 1990 & 1996 & 2007 & 2012 & 2017 \\
\hline Number of farms (in thous.). & 2167.6 & 2137.5 & 2041.4 & 1804.1 & 1476.7 & 1405700 \\
\hline 1 - 2 ha (\%) & 18.7 & 17.7 & 22.6 & 23.4 & 20.2 & 18.7 \\
\hline $2-5$ ha (\%) & 34.8 & 35.1 & 32.7 & 34.0 & 32.6 & 32 \\
\hline 5 - 10 ha (\%) & 29.3 & 29.8 & 25.5 & 22.2 & 23.8 & 22.5 \\
\hline 10 - 15 ha $(\%)$ & 11.2 & 11.3 & 10.6 & 9.2 & 9.8 & 10.1 \\
\hline 15 - 20 ha $(\%)$ & \multirow{3}{*}{6.0} & \multirow{3}{*}{6.1} & 4.4 & 4.3 & 5.0 & 5.0 \\
\hline $20-50$ ha $(\%)$ & & & 3.7 & 5.7 & 6.8 & 7.7 \\
\hline$>50$ ha $(\%)$ & & & 0.5 & 1.2 & 1.8 & 2.5 \\
\hline$<1$ ha $\quad(\%)$ & & & & & & 1.5 \\
\hline
\end{tabular}

Source: Baer-Nawrocka, Poczta (2014), Sobiesiak-Penszko, Pazderski, Jakubowska-Lorenz (2019)

Figure 1: Share of agricultural workers in total employment in per cent in Poland in period 2000- 2017

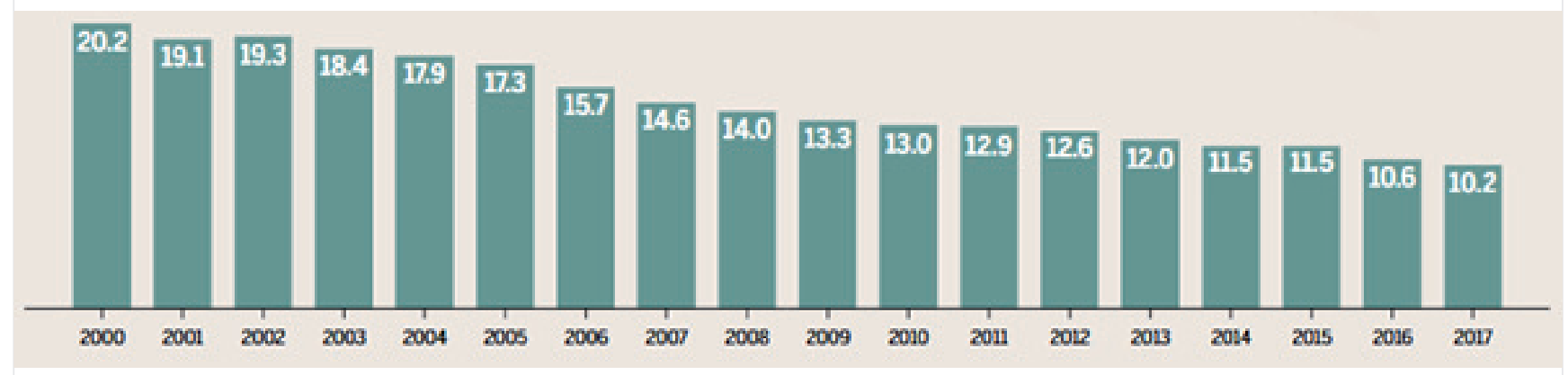

Source: Agricultural Atlas (2019)

also by the fact that majority of farms have agricultural land scattered in several plots, often located in a considerable distance.

As a result of many historical, economic and cultural factors, changes in the shape of the area structure of farms are slow. However, there is a tendency to slowly decrease the number of the farms with the smallest area (up to 10 hectares), and to increase the number of farms with more than 20 hectares (in 2010, farms with 20 hectares to 49.99 hectares accounted for $6.4 \%$ of all farms, in $2017-7.7 \%$ ) and farms over 50 hectares (between 2010 and 2017, the share of these farms increased from $1.8 \%$ to $2.5 \%$ ).

In 2018, farms covered 16.4 million ha of land. According to the Central Statistical Office (2019), last year the number of farms with arable land was about 1 million 425 thousand which covered 16.4 million ha of land. This is $1.4 \%$ more than in 2017. Let us add that farms with an area above 1 ha of agricultural land were around 1 million 401 thousand (including 1 million 180 thousand having sown area). In 2018, the number of farms over 500 ha occupied $6.9 \%$ of the total land area and the total number was $759^{(9)}$.

In 2017, the 20\% of the biggest farms received the lion's share - 74\% - of the direct (area) payments. The remaining four-fifths of farms had to be content with a little more than one-quarter of the funds. The focus on area payments meant less money was available for agri-environmental programmes

(9) Central Statistical Office (2019) or to support sustainable rural development.

As a result, the EU funds had only a modest effect on reducing inequalities between farms in different regions. The income disparities between farmers increased significantly.

\section{Aspects of structural development of Polish agriculture}

Since 2000, the number of people employed in agriculture has been gradually decreasing. In the period from 2001 to 2017, the share of people working in agriculture reduced twice. This is a positive aspect. A less optimistic process, however, is the slow change in the structure of farms. Based on the Central Statistical Office's data, 12276500 hectares are used by 1141000 family farms with an average area of 8.7 hectares. The next group of users is both family and non-family workers. There are 11100 such holdings occupying an area of 823 100 ha. The average area is 74.2 ha. Last group consists of farms based $100 \%$ on a hired work force occupying an area of 1310000 ha. There were 3700 of such farms with an average area of 354.1 ha.

As mentioned in the introduction of this study, although considerable fragmentation of farms can be seen beneficial in terms of biodiversity, from the point of view of sustainable development, an environmental, social and economic balance 
should be reached. Excessive fragmentation of production and the production costs increase significantly which can lead to a simplification of the production. Moreover, it encourages production performed in a manner inconsistent with the principles of good agricultural practice. Therefore, a model should be developed in a way that it allows for concentration of agricultural land in farms with an average size of about 30 ha. ${ }^{(10)}$

\section{Sustainable agriculture}

Poland's farms now fall into three categories. About 20\% of farms are big producers that sell all of their output. Within this category, some farms use highly intensive production methods. They sow large-scale crop monocultures, use huge amounts of mineral fertilizers and pesticides, and simplify the rotation of crops. This has an enormous impact on the environment, it:

- degrades the soil and landscape,

- reduces biodiversity,

- pollutes groundwater and surface water.

Industrial animal raising methods such as caged production or year-round confinement cause suffering to animals. These methods also produce huge amounts of slurry, contaminating water and soil. Industrial agriculture also inhibits the development of rural areas, leading to depopulation. Because the farmers who for years have applied traditional crop and animal production methods are no longer able to compete with big farms, they give up farming altogether.

At the other end of the scale, the smallest farms maintain the land in good condition but produce either nothing (about 15\% of farms) or as much as they need for their personal consumption (about 10\%). Many of them have been forced out of the market by the growing competitiveness of the large farms.

The third category is also the largest. It includes over half of all Polish farms. These farms are trying to survive through commercial production but they are too small to benefit from economies of scale. As a result, they seek a competitive edge by specializing or by cutting costs - for example, by simplifying crop rotations or reducing liming and the use of organic fertilizers. Such practices are important to maintain the environment. A major challenge for agricultural policy is to preserve these farms and ensure that they can produce food in accordance with good agricultural practices. The farmers who manage these enterprises are crucial for the sustainable development of rural areas. By maintaining land in good condition and by producing food less intensively than big farms, they have a positive impact on the environment, preserve biological and landscape diversity and counteract the depopulation of rural areas.

Sustainable agricultural production method is characterized by the use of fertilizer nutrients adjusted to the needs of the plants. Total consumption of mineral fertilizers remained in Poland since 2005 at a similar level of about 20.5 million $\mathrm{Mg}$ in 2017 and it is almost 30\% lower than in the 80's and in 1990, but it is almost two times higher than in the first half of the 90 's. This increase can be linked to the average consumption of fertilizers per unit area of agricultural crops, which in the

(10) Agriculture Atlas (2019) period 1991 - 2012 has increased twice: in 1991 it amounted to approx. $62.1 \mathrm{~kg} / \mathrm{ha}$, and in 2017 already approx. $125 \mathrm{~kg} / \mathrm{ha}$. Although the average consumption of fertilizers in Poland is not high, in areas exposed to pollution by nitrates from agricultural sources of nitrogen dose allowed in organic fertilizers (manure) up to $170 \mathrm{~kg}$ (in pure ingredient/ha), the method of fertilization differ significantly from the principles of sustainable agriculture. The commodity demand leads only the largest farms to constantly monitor the soil nutrients and on its basis to prepare annual plans and to apply fertilizers. Other fertilizers are used in a random manner and it is not very controlled. The result is that agriculture is the main source of eutrophication in Poland.

On the other hand there is a worrying drop in calcium fertilization (to de-acidification of soils) of $117.2 \mathrm{~kg} / \mathrm{ha}$ to approximately $34 \mathrm{~kg} / \mathrm{ha}$ ). This creates a significant threat to the stability of agricultural production due to the high proportion of acidic soils in Poland. In an acidic environment, easily accessible to plants, there remain contaminants in the soil - especially heavy metals, but also pesticide residues. Acidic soils have a limited production capacity, which causes a decrease in the size of the yield earned on them. Acidification of soils affects biodiversity. Problems of improper use of fertilizers and liming grow despite the broad educational activities carried out by the agricultural advisory services. The concern is also about the increase in the use of pesticides, which occurred after Poland's EU accession.

Although the data presented in the Figure 4 do not fully reflect the size of the consumption of plant protection products, as the present volume of their sales in the Polish market, it is likely that they accurately reflect the growing trend of increased consumption of pesticides in the Polish agriculture. According to these data, the current consumption is three times higher than in 1991. It seems that in reality there has not been such a significant increase in the use of pesticides, but the data from the previous years were not very accurate (they inflated the data resulting from the adopted methods of statistical surveys). However, it can be assumed that the increase in the use of pesticides was due to the progressive specialization of farms and new intensive varieties and plant species. Positive development in this regard is the introduction of new standards for the use of pesticides and training of persons engaged in these efforts. This reduces the risk of environmental pollution as well as consumer health as a result of improper use of these chemicals.

\section{Technical infrastructure as important factor of rural development in Poland}

Rural areas are not only a place of agricultural production and farming, but also because of favourable environmental conditions, more common place for living, which would be impossible without an efficient modern infrastructure. The phenomena are benefiting from the changes of common agricultural policy aiming at creating conditions for development of rural 
areas in the direction favouring the development of society. As a result of the support of society development in rural areas and construction of necessary infrastructure, the accessibility of the areas outside the city increases for more people. This results in increase in property values and better management of land. This favours the rationalization of land use in rural areas and the competitiveness of agricultural production. In the past, the state did not pay proper attention to the development of technical infrastructure. As a result, a barrier to the development of not only agricultural production but also to the development of rural society was formed.

An essential condition for the effective functioning of the economy is the development of rural infrastructure, including technical infrastructure. The production in large areas is impossible without roads, efficient transport, communications, water supply and energy. The lack of waste collection systems and sewerage systems threatens the natural environment and the functioning of rural settlement. The large spatial dispersion is one of the main difficulties in the development of infrastructure in rural areas. The total number of villages in Poland is 52.5 thousand, including 43 thousand villages and 9.5 thousand hamlets and settlements/colonies ${ }^{(11)}$. In numbers, rural villages with less than 100 people constitute 15\%,66\% are villages inhabited by 100 to 500 individuals, $13 \%$ by 500 to 1000 individuals and only $6 \%$ of villages are inhabited by more than 1000 people. According to the data of Central Statistical Office, there are 18200 (32\%) compact villages (with distance between farms up to $45 \mathrm{~m}$ ), 27\% villages with dispersed housing (just above $200 \mathrm{~m}$ ) and $41 \%$ with intermediate distances between farms ${ }^{(12)}$.

The confirmation of the importance of these problems is the inclusion of the level of equipment in rural areas with technical infrastructure by the World Bank as the main factor for the development of rural areas and agriculture. In the opinion of the World Bank, infrastructure not only has a direct impact on the quantitative level of the agricultural production but also on the development opportunities of these areas in order to attract domestic capital and investment services. The EU policy, conducted in the infrastructure development for many years, aims at creating conditions for its availability in all EU countries in order to diminish the civilization gap, separating the rural areas from the urban areas, and to create equal opportunities of competitiveness in the rural areas. An equally important aspect taken into account by this policy is to prevent the depopulation of rural areas, which has an adverse impact on the sustainable development of the countries. A modern village is no longer synonymous to agriculture, but it is different from the city as a place for life and work of various groups of people that apart of diverse professions, form a community with common cultural issues, traditions, norms of coexistence and interests. Awareness and environmental sensitivity of the inhabitants of the rural areas will be shaped not through orders and penalties, but foremost, by education. As long as farmers do not benefit from the environmental protection, they will not be interested in maintaining clean environment. Environmental education in Poland is generally of negative nature. It is based on provid-

\footnotetext{
(11) MRiRW (2014)

(12) Wierzbicki, Krajewski (2004)
}

ing information on activities that harm the environment and their consequences (often frightening), and does not give tips, recommendations or advice how the problems can be solved. Neglecting this step may result in obtaining the suspension of pro-ecological activities of local communities, struggling with the problem.

Environmental protection is a complex issue especially in the rural areas. Sustainable development of rural areas is the way of managing, which links economic, social and ethical principles with ecological safety. This may be reached by proper management, directed on cautious usage of ecosystems' self-controlling mechanisms, with the progress of science and technology. Apart from the above-mentioned facts, natural resources should be exploited without interruption of the ability of their self-renovation. Increasing production of biomass may be treated as an effect of the increase in the productiveness of the resources, which means introduction of new technologies and, at the same time, protection of resources and retaining of the high quality resources for the future generations.

\section{Conclusions}

Evaluation of Polish agricultural sustainability is not clear. On the one hand, there is improved economic situation of farmers, increasing agricultural productivity and produced added value by the sector. Through the effective use of the EU funds the improved infrastructure in the rural areas has increased the number of households connected to the water supply and sanitation. Rural areas have begun to operate the company responsible for the proper management of waste. EU programs also allowed farms to be better equipped by machinery and equipment necessary to conduct effective production. The introduction of new technology and modern machinery has increased the efficiency of agricultural production - increased yields of crops and the efficiency of livestock production, which increased the income of farmers.

However, there are negative phenomena too. One is the aging of the rural population and rural exodus of young people. The latter one has become massive after Polish accession to the EU and the opening of the labour market in more developed countries (United Kingdom, Germany). According to data from the end of 2018, 2.5 million Poles live in emigration, of which 90\% remains in Europe. The number of Polish citizens who decided to move out of the country systematically was 2 million in 2010. Although to a large extent, this process prevents the rural unemployment, in many areas it leads to the problem of consequences on farming. Despite this, the market did not develop the land, making it difficult to increase the efficiency of agricultural production.

An important problem is the social stratification of the rural income. Besides, modern medium and large farms often operate more socially, what does not lead to agricultural production but producing only for their own needs. This creates important agricultural policy dilemmas - whether it should support the household perspective and combat poverty and social exclusion. In the opinion of some experts, only approx. a 100 thousand farms (whose income exceeds 16 ESU) in Poland has a chance to develop and achieve parity income. In addition, 100 - 150 thousand lower income households can produce 
goods, but their profitability will depend on the possibility of obtaining additional income outside of agriculture. But will the agriculture, in which instead of the usual 1.5 million farms remain only 200000 - 250000 , be the sustainable agriculture?

Polish accession to the EU has brought a number of positive changes. Access to the EU funds for the rural development has allowed to accelerate the process of building the infrastructure to protect the environment and to implement the principles of the Common Agricultural Policy. Farmers need to apply the principles of the Code of the Common Good Agricultural Practice, maintaining agricultural land in good agricultural condition and implement the requirements of Cross Compliance. Access to the agri - environmental subsidies for organic farming meant that there significantly increased the surface on which method of agricultural production is subordinated to the requirements of the environmental protection and nature conservation.

Rural areas are changing fast, both in Poland and worldwide, as they adjust to globalization. Some of these processes - industrial farming, rural depopulation, the conversion of farmland into the residential suburbs, the loss of local culture are negative, and pose a threat to the multifunctionality of the rural areas. In Poland, no measures have been implemented to counteract such changes. Agricultural policy needs to give more support to the many functions that the countryside performs in addition to its food-producing role.

Unfortunately, many environmental problems still remain unsolved, and the membership in the EU has led to the emergence of new ones. As a particular threat should be regarded the earlier discussed loss of agricultural land and transferring of agricultural and forest land (including the highest class) into non-agricultural and non-forest purposes. Intensification of production is the threat to biodiversity - both through increased consumption of fertilizers and pesticides, and by simplifying the landscape (removal of copper-field, creating large areas of monoculture crops) and crop rotation.

Therefore, the most appropriate summary is that Polish agriculture is not excessively balanced or unbalanced. The process of the European integration and the introduction of instruments of the Common Agricultural Policy have created an opportunity that will support a sustainable agricultural model that will be based on medium-sized farms, leading to not very intensive agricultural production. The construction of such a model will, however, require a significant number of educational activities and compliance with all tools and instruments used by the state in relation to the agriculture and rural areas. Producing high-quality food is an essential role of rural areas. But the countryside has also other important functions. It is a home to many people, and it plays a major part in maintain- ing the natural environment. Unfortunately, these functions do not get enough support in Poland.

\section{References}

1. AGRICULTURE ATLAS. 2019. Facts and figures on EU farming policy. Heinrich Boll Foundation, Berlin, Germany, Friends of the Earth Europe, Brussels, Belgium p.72.

2. AGRIFOOD ATLAS. 2017. Facts and figures about the corporations that control what we eat. Heinrich Böll Foundation, Berlin, Germany, Rosa Luxemburg Foundation, Berlin, Germany, Friends of the Earth Europe, Brussels, Belgium.

3. BAER-NAWROCKA, A., POCZTA, W. 2014. Changes in agriculture [in] Polish village in 2014. Report on the state of the village. Nurzyńska I., Poczta W. (eds). Ed. FAPA. Warszaw.

4. EUROSTAT. 2019. Online. [Cited 12. 05. 2019]. Available at: <http://epp.eurostat.ec.europa.eu/tgm/refreshTableAction.do;jse ssionid=9ea $7 \mathrm{~d} 07 \mathrm{~d} 30 \mathrm{db} 8 \mathrm{bad} 194 \mathrm{c} 13 \mathrm{fb} 44629 \mathrm{ac} 38 \mathrm{aalb66697b5}$. e34MbxeSaxaSc40LbNiMbxeNb34Ke0?tab=table\&plugin=1\&p code $=$ tsdpc 100 \&language $=e n>$.

5. KARACZUN, Z., KASSEMBERG, A., OWCZAREK, D. 2015. Governance of Sustainable Development Goals (SDGs). National case study-Poland. Manuscript.

6. KARLSSON, I., RYDÉN, L., SEPP, K. 2013. Introduction. In: Rural Development and Land Use. Uppsala University, Baltic University Press, p. 11-19.

7. KRASOWICZ, S. 2012. Problemy zrównoważonego rozwoju rolnictwa polskiego w świetle badań IUNG-PIB. Studia i Raporty IUNG-PIB 29(3): 21 - 49

8. MRIRW. 2014. Program Rozwoju Obszarów Wiejskich na lata 2014-2020

9. SOBIESIAK-PENSZKO, P., PAZDERSKI, F., JAKUBOWSKA-LORENZ, E. 2019. Perspektywy zrównoważonego rolnictwa w Polsce . Analiza społeczno-polityczna.

10. WIERZBICKI, K. KRAJEWSKI, K. 2004. Zagrożenie konkurencyjności gospodarstw rolnych wobec niedorozwoju infrastruktury technicznej wsi polskiej. W: Realizacja ustawy o kształtowaniu ustroju rolnego. FAPA, 129-162.

11. WILKIN, J. 2014. The balance of the decade of Poland's membership in the European Union in terms of agriculture and rural areas. Chapt. 1. In: Rural Poland 2014, Rural Development Report, $11-26$.

12. EGOSPODARKA. 2014. Polskie ceny ziemi rolnej w pogoni za Europa, 2014. Online. [Cited 10. 01. 2015]. Available at: http:// www.nieruchomosci.egospodarka.pl/119092,Polskieceny-ziemi-rolnej-w-pogoni-za-Europa,1,80,1.html.

\section{Contact address/ Kontaktná adresa}

prof. dr hab. Józef Mosiej

Faculty of Civil and Environmental Engineering

Department of Environmental Management

Warsaw University of Life Sciences, Poland

e-mail: jozef_mosiej@sggw.pl 